\title{
Editorial: Special focus on the functional dimensions of the right to development
}

\section{Carol C Ngang*}

Researcher, Free State Centre for Human Rights, University of the Free State, South Africa

https://orcid.org/0000-0001-7222-4693

The shift in development thinking from the narrow focus on economic growth towards a combined focus on human rights and development that occurred in the 1990s witnessed the birth of a range of rights-based approaches with a common goal to achieve larger human freedoms, improved well-being and to redress the multiple effects of poverty that continues to amplify underdevelopment and the myriad of other developmental challenges. While Marks identifies seven of the rights-based approaches, ${ }^{1}$ including the right to development, it is worth stating that the right to development existed long before other rights-based approaches to development came into existence. Although the composite framework for human rights and development makes room for a plurality of models for achievement, Perry observes that the right to development uniquely combines the multifaceted dimensions of development, poverty eradication and human rights. ${ }^{2}$

In spite of this optimistic perception, the right to development has not been sufficiently explored to the betterment of the livelihood circumstances of the impoverished. With the universal acknowledgment that there is a right to development, albeit that most developed countries do so only in principle, the peoples of the developing parts of the world to whom it has relevance should by their entitlement to such a right be assured of the full enjoyment of the substantive

* LLB (Yaoundé) IDHA (Fordham) SUSTLAW (Antwerp) LLM LLD (Pretoria); NgangCC@ufs.ac.za

1 SP Marks 'The human rights framework for development: Seven approaches' (2003) François-Xavier Bagnoud Centre for Health and Human Rights 12.

2 R Perry 'Preserving discursive spaces to promote human rights: Poverty reduction strategy, human rights and development discourse' (2011) 7 McGill International Journal of Sustainable Development Law and Policy 78. 
guarantees that are embodied in what development is intended to achieve. The concept of development is quite ambiguous; often understood in very relative terms and not subject to any universallyacceptable standard. Our working definition of development draws from the human development index model that measures development in terms of living standards. ${ }^{3}$

No matter how development is perceived and whatever form it takes, it ultimately aims at the attainment of improved well-being for the human person, especially for the peoples in developing countries. Based on this understanding, the right to development would be said to have been achieved when an equilibrium in living standards has been attained for all peoples or, at minimum, achievable when the systems and opportunities are created and made accessible for all peoples to equally aspire for the highest attainable standard of living guaranteed to all peoples. ${ }^{4}$ Looking beyond the controversies and the inadequacies that have constrained the realisation of the right to development, it is vital to admit that the dearth of research on the subject has played a significant role.

Part of the commitment to ensure that the abstract guarantees on the right to development translate into creating a sustainable impact is to ensure that its composite dimensions sufficiently inform policy measures on the obligation to create the conditions and to facilitate the processes to drive an effective right to development practice and consequently to maximise aspirations for better living standards and improved human well-being. In accordance with human rights standards, the responsibility to achieve this purpose is attributed to the state. The Declaration on the Right to Development stipulates that '[s]tates have the right and the duty to formulate appropriate national development policies that aim at the constant improvement of the well-being of the entire population and of all individuals', and the primary responsibility to create the conditions favourable to the full realisation of the right to development. ${ }^{5}$ The African Charter on Human and Peoples' Rights (African Charter) also provides as a matter of binding law that '[s]tates shall have the duty, individually or collectively, to ensure the exercise of the right to development ${ }^{\prime}{ }^{6}$

This special focus section of the African Human Rights Law Journal explores these functional requirements to illustrate some policy and practical measures with regard to what implementation entails and how the right to development may apply in actual circumstances. All

3 United Nations Development Programme Human Development Report 1990 (1990) 9-16.

4 Universal Declaration of Human Rights adopted by the United Nations General Assembly, Resolution $217 \mathrm{~A}(\mathrm{III})$ of 10 December 1948 Preamble para 8.

5 Arts 2(3), 3(1) \& 4(2) Declaration on the Right to Development Resolution A/RES/ $41 / 128$ adopted by the UN General Assembly on 4 December 1986.

6 Art 22(2) African Charter on Human and Peoples' Rights adopted by the Organisation of African Unity in Nairobi, Kenya on 27 June 1981,OAU Doc CAB/ LEG/67/3 Rev 5; 1520 UNTS 217. 
six contributions in this special focus section fundamentally concur in the argumentation that the implementation of the right to development remains a major concern and, accordingly, point out the lapses as well as the policy and practical measures that need to be taken. Two of the contributions examine the right to development globally within the context of international law and the Sustainable Development Goals; three are centred on Africa with an emphasis on matters relating to structural transformation; and one is more countryspecific as it explores the right to development with regard to transformative constitutionalism in South Africa.

Igbinedion assesses the value of the right to development under international law which, he argues, provides a feeble framework for implementation, particularly taking into consideration the challenges of underdevelopment in sub-Saharan Africa. He argues that the lack of defined roles for rights holders and duty bearers misleads developing countries into vain expectations of assistance in their development efforts. He suggests a deconstruction of the current international law architecture on the right to development as a means to ensure its enforceability.

De Man's contribution explores the extent to which the global sustainable development framework for development incorporates the realisation of human rights into the development goals that are envisaged to be achieved by 2030 . She makes the point that although the sustainable development agenda is compatible with rights-based standards, particularly in the area of participation, it primarily is limited in terms of implementation as well as monitoring and evaluation to ensure that the full spectrum of advantages offered under rights-based approaches to development can be achieved.

Focusing on the 2063 African agenda for development, Stevens looks at the World Trade Organisation with the aim to determine how African member states could explore the multilateral trade system to 'raise standards of living', 'ensure full employment' and 'sustainable development' through advancing the right to development within the trade discipline. With reference to multilateral trade practices, programmes and policies, she argues in favour of the right to development within the multilateral trade framework, which she says is a valuable tool for actualising the structural transformation objectives contained Agenda 2063.

Kamga takes a pan-African view in looking at the right to development in Africa where the aspiration for freedom, equality, justice and development remains a far-fetched idea. He makes the argument that a right to development-informed pan-Africanism has the potential to expand opportunities for development for the African people. He posits a reconceptualised form of pan-Africanism that emphasises Africa's sovereignty over its natural wealth and resources and the obligation to adopt a people-centred constitutionalism and responsive national policies to ensure the well-being of the African peoples. 
Ngang's article demonstrates that Africa is confronted with a systems problem resulting from the lack of an adequate model to deliver on the promise to accelerate improved standards of living and the attainment of human well-being in larger freedom for the peoples of Africa. To this end he gives an account of the right to development governance as a functional model with the potential to actualise the collective advancement of Africa, which guarantees to the impoverished African peoples the entitlement to socio-economic and cultural development and redress on the range of other daunting development challenges on continent.

In exploring the question whether transformative constitutionalism, which is interpreted to imply the right to development, could achieve radical transformation in South Africa, Shai contends that it is unattainable because of insufficient theorisation of what radical transformation actually entails. He suggests that instead of pursuing transformative constitutionalism and the right to development as a means to achieve radical transformation, radical transformation should rather be seen as the starting point to inform transformative constitutionalism and the right to development. 